\title{
Verkkoa, oppimista ja vähän kaikkea siltä väliltä
}

Nieminen, J. (toim.). (2002). Verkot ja virtuaalistaminen oppimisen tukena. Hämeen ammattikorkeakoulu

Suomalaisesta kirjallisuudesta on vähitellen löydettävissä suorastaan virkistävän paljon erilaisia näkökulmia verkko-oppimiseen. Tässä Aikuiskasvatus -lehdessä arvioimistani kirjoista Matikaisen teos korostaa verkko-oppimisympäristöjen vuorovaikutuksellisuutta, kun taas Sallilan \& Kallin toimittamaa teosta voidaan pitää erittäin tasokkaana verkko-oppimisen yleiskoontina, eräänlaisena käsikirjana. Yhteistä edellä mainituille teoksille on, että niissä painotetaan verkko-oppimisen haasteita erityisesti opiskelijoiden tarpeista käsin.

\section{Niemisen toimittamassa} teoksessa tarkastelun kohteena ovat sen sijaan ensisijaisesti aikuispedagogiikan ammattilaiset. Teoksessa esitellään valtakunnallista TUKEVA-hanketta, johon sisältyy niin tutkimusta, kehittämistä kuin valmennustakin. Hanke on startannut vuonna 1998, ja toimintaa on tarkoitus jatkaa vuoteen 2006 saakka.

TUKEVA:n tavoitteena on aikuiskouluttajien osaamisen nostaminen työssä tapahtuvan tutkintotavoitteisen ja verk- koperusteisen opiskelun avulla. Kirjan tarkoituksena on vastaavasti suorittaa väliarvio TUKEVA:n etenemisestä. Laajana tavoitteena on esittää teoreettisia arvioita ja empiirisiä esimerkkejä siitä, mihin ammatillinen aikuiskoulutus on Suomessa menossa ja mitä välineitä koulutuksessa hyödynnetään. Erityisenä tavoitteena on arvioida verkkoperusteisen oppimisen toteuttamismahdollisuuksia. Teoksen kirjoittajina on sekä hankkeeseen osallistuvia että toteuttamisesta vastaavia asiantuntijoita. TUKEVA vaikuttaa hankkeena erittäin tarpeelliselta. Verkko-oppimisen lopullisen läpimurron ehdotto- 
mana edellytyksenä on aikuiskouluttajien halu ja kyky hyödyntää verkkoperusteisia oppimisratkaisuja. Itse kirja ei sen sijaan vastaa kovinkaan kattavasti sille asetettuihin tavoitteisiin. Vaikka verkko-oppimisen ja erityisesti aikuiskouluttajien verkko-oppimistarpeiden arviointi on asetettu kirjan keskeisiksi tavoitteiksi, niitä käsitellään artikkeleissa vain nimellisesti. Lisäksi artikkelit ovat triviaaleja, selkeästi eritasoisia ja sisällöiltään vaihtelevia, mikä jättää kirjasta kokonaisuutena epäyhtenäisen, jopa hieman sekavan vaikutelman.

\section{Ruohotie käsittelee}

artikkelissaan kvalifikaatioiden

ja kompetenssien kehittämistä koulutuksen tavoitteina. Ruohotie tekee sinänsä ansiokasta käsiteanalyysia kvalifikaatioista ja kompetensseista, mutta käsitteiden merkittävyys verkko-oppimisen kannalta jää analyysista puuttumaan. Samoin voi todeta Tunkkarin artikkelista, jossa käsitellään mentorointia oppimisen menetelmänä. Myöskään tässä artikkelissa ei ole yhtymäkohtia verkko-oppimiseen, vaan Tunkkari pitäytyy vahvasti mentoroinnin käsitteellisessä tarkastelussa. Saarisen, Kuuselan ja Siekkisen artikkeleissa verkko-oppiminen on sitä vastoin selkeästi esillä. Artikkelien näkökulmat eivät kuitenkaan ole kriittisiä, vaan kirjoittajat esittävät lähinnä teknisiä kuvauksia ja ohjeistuksia verkko- tai videoperusteiseen opetustilanteeseen valmistautumisesta ja opetuksen toteuttamisesta. Viimeisessä varsinaisessa sisältöartikkelissa Mahlamäki-Kultanen kuvaa maaseudun PK-yritysten informaatioteknologian käyt- tövalmiuksia. Kohderyhmän valinta on sinänsä mielenkiintoinen, sillä maaseudulla verkkoratkaisujen ajallisesta ja paikallisesta riippumattomuudesta voisi olettaa olevan erityistä hyötyä pitkien maantieteellisten etäisyyksien vuoksi. Mahlamäki-Kultasen kartoitus koskee kuitenkin maaseudun PK-yrittäjien informaatioteknologian käyttövalmiuksia yleisellä tasolla. Siten myös tämän artikkelin merkittävyys verkko-oppimisen kannalta jää varsin vähäiseksi.

\section{Teoksen varsinainen}

hyöty verkko-oppimisen kannalta tulee esiin Linturin loppuyhteenvedossa. Linturi pohtii ansiokkaasti verkkooppimisen yhteiskunnallista merkitystä neljän, Freiren ajatuksia hyödyntävän näkökulman kautta. Ensimmäinen näkökulma kuvaa verkko-oppimisen murrosaikakautta, toinen evolutiivisia kehitysvaiheita, kolmas Internetix Campus kokeilua ja neljäs tulevaisuuden haasteita ja mahdollisuuksia. Linturi sijoittaa verkko-oppimisen informaatioyhteiskunnan murrosvaiheeseen, jolle on ominaista verkottuminen, globalisoituminen ja digitaalistuminen. Verkkooppimisympäristöjen evoluution ensimmäisessä vaiheessa kouluinstituutioiden tavoitteena oli siirtää oppimateriaali ja palvelut sellaisenaan verkkoon. Toisessa, laajenemisvaiheessa verkko-oppimisen tavoitteita ja menetelmiä alettiin eriyttämään lähiopetuksesta, jolloin esimerkiksi perinteisiä kokeita ryhdyttiin korvaamaan oppimistehtävillä. Kolmannessa, syvenemisvaiheessa oppimispalvelujen tuottajiksi tuli myös yrityksiä, minkä seurauksena oppimi- nen muuttui yhä monipuolisemmaksi ja vuorovaikutuksellisemmaksi. Neljännessä, läpimurtovaiheessa verkko-oppimista alettiin hyödyntämään kaikilla merkittävillä yhteiskunnan aloilla. Linturin esittelemä Internetix Campus on konkreettinen esimerkki juuri verkko-oppimisen yhteiskunnallisesta hyödyntämisestä. Internetix Campus on osittain avoin ja osittain maksullinen verkko-oppimisympäristö, joka tarjoaa palveluja kaikille kouluasteille ja useille toimialoille. Internetixin valtavan tietomäärän kehitys ei ole yhden palvelujen tuottajan varassa, vaan Internetix on ameebamainen, usean asiantuntijatahon ylläpitämä ja kehittämä oppimisympäristö. Internetixin ja muiden verkko-oppimisympäristöjen suuri tietomäärä johtaa kuitenkin myös suuriin haasteisiin. Linturi näkee verkko-oppimisen tulevaisuuden ongelmat niin teknisinä, vuorovaikutuksellisina kuin yhteiskunnallisinakin. Haasteista huolimatta kehityksessä ollaan jo niin pitkällä, että verkko-oppimisparadigman etenemistä on enää vaikeata pysäyttää.

\section{Vaikka Linturin loppu-}

yhteenveto on tasokas, se ei valitettavasti riitä pelastamaan koko teosta. Kirjassa on sen tavoitteisiin nähden niin paljon säröjä, että sille on vaikeata löytää selkeätä kohderyhmää. Mutta ehkä lopullisena tarkoituksena ei olekaan tavoittaa suurta yleisöä, vaan ennemminkin selkiyttää TUKEVA:n eri sidosryhmille hankkeen etenemistä. Tähän tarkoitukseen teos soveltuu varmasti mainiosti.

Ville Pietiläinen 